\section{. Journal BiNET}

Journal of Bioscience and Agriculture Research

Home page: www.journalbinet.com/jbar-journal.html

\title{
Influence of BAP and NAA on in vitro plantlet regeneration of local and exotic banana cultivars
}

\section{Md. Anwar Hossain ${ }^{\mathrm{a}}$, Mehede Hassan Rubel ${ }^{\mathrm{b}}$, Khondoker M. Nasiruddin ${ }^{\mathrm{c}}$ and Fatematuz Zuhura Evamoni ${ }^{\mathrm{a}}$}

${ }^{a}$ Dept. of Biotechnology and Genetic Engineering, bept. of Agriculture, Noakhali Science and Technology University, Sonapur, Noakhali

'Dept. of Biotechnology, Bangladesh Agricultural University, Mymensingh, Bangladesh

\begin{abstract}
The study was conducted to assess the influence of BAP and NAA on in vitro plantlet regeneration of local and exotic banana cultivars. Shoot tip of the cultivars Grand Naine, Amritasagar and Sabri were used as explants for establishment of culture. Different concentrations of BAP (1.0, 2.0, 3.0, 4.0, 5.0 and $6.0 \mathrm{mg} / \mathrm{L}$ ) were used in MS medium to study their effects on shoot formation. Explants of all the cultivars produced both single and multiple shoots but rate of shoot regeneration varied among different cultivars and BAP concentrations. The highest shoot regeneration was found in all the three cultivars at $5.0 \mathrm{mg} / \mathrm{L}$ of BAP. Among the three banana cultivars Grand Naine produced the highest shoot. Shoot proliferation rate of Grand Naine, Amritasagar and Sabri was 3.50, 3.25 and 1.75 (per explant) respectively was obtained after 30 days of culture. MS medium supplemented with different concentrations of NAA $(0.5,1.0,2.0,4.0$ and $6.0 \mathrm{mg} / \mathrm{L}$ ) were used for in vitro root formation from proliferated shoots. The cultivars Grand Naine showed the best root forming performance in all concentrations of NAA. Best results of root formation were observed on MS medium supplemented with $4.0 \mathrm{mg} / \mathrm{L} \mathrm{NAA}$. All the plantlets regenerated in vitro from shoot tip explants of three banana cultivars survived in the field condition but Grand Naine showed the superior performance.
\end{abstract}

Keywords: BAP, NAA, plantlet, regeneration and banana cultivars

Please cite this article as: Hossain, M. A., Rubel, M. H., Nasiruddin, K. M. \& Evamoni, F. Z. (2016). Influence of BAP and NAA on in vitro plantlet regeneration of local and exotic banana cultivars. Journal of Bioscience and Agriculture Research, 06(02), 553-564.

This article is distributed under terms of a Creative Common Attribution 4.0 International License.

\section{Introduction}

Banana (Musa spp.) and plantains belonging to the family Musaceae are the most ancient food plants having being used all over the world and make a major contribution towards the world's total food production (FAO, 1987). The fruits are highly nutritious; contain large amounts of carbohydrates and minerals such as phosphorus, calcium and potassium as well as vitamins $\mathrm{A}$ and $\mathrm{C}$ and significant amount of several other vitamins (INIBAP, 1987). Throughout the tropical and sub-tropical regions, more than 100 countries cultivate banana (Sharrock and Frison, 1999). It is a staple food for nearly 400 million people and is an essential source of income for many national economics with world imports in 1995 valued at \$USA 5.3 billion (Sasson, 1997). Among the fruit crops grown in Bangladesh, 
banana ranks first in terms of production and second in terms of area, comprising nearly $42 \%$ of the total fruit production of the country. Banana occupied an area of 40 thousand hectares of land and produced 572 thousand matric tones with an average yield of $14.16 \mathrm{t} \mathrm{ha}^{-1}$ (BBS, 2003).This yield is quite low compared to other banana growing countries like Argentina (34 tha-1) and Costa Rica (33 t

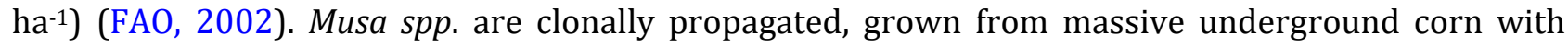
highly compressed internodes (Barker and Steward, 1962) and are subjected to attack by a wide range of diseases and pests (Cronauer and Krikorian, 1983) which are carried over through generations and affect the yield. Consequently, production of fruits reduces that result poor harvest which affects normal economy. To conquere the situation, we need to produce disease free plant materials. It will enable us to produce quality foods. In this respect genetic engineering can play a major role to overcome the existing constrains by introducing specific genetic changes which will enable us to produce banana within short period of time. To implement the process in the field we need to heve a reliable plant regeneration protocol.

Banana tissue culture is a first-generation plant biotechnology tool used to reduce the spread of pests and diseases, especially fungal and bacterial wilt diseases, by making disease-free planting material available for the propagation of new crops. Simple tissue culture techniques such as shoot-tip and embryo culture are well-developed in Africa. In terms of yield performance, tissue cultured plants have been reported to produce 39\% higher yield than plants from sword suckers (Pradeep et al. 1992). Under Bangladesh situations, tissue culture derived plantlets of banana performed better than the conventional sword suckers (Faisal et al. 1998). Phytohormones are important for in vitro regeneration of crop plants grown in any synthetic medium. Generally, cytokinin helps in shoot multiplication and auxin helps in root formation of multiplied shoots. Commonly, the requirement of cytokinin and auxin depends on the variety of banana and culture conditions (Cronauer and Krikorian, 1984). Therefore, the present investigation was undertaken with the following objectives: i) to determine the suitable concentrations of BAP and NAA on in vitro regeneration of banana cultivars, ii) to allow for the rapid multiplication of uniform and high quality clonal planting materials and iii)to supply planting material in large quantities especially for large-scale cultivation.

\section{Materials and Methods}

Planting materials were the shoot tips of banana cultivars namely, Grand Naine ( $M$ cavendeshii, Genotype AAA), Amritasagar (M sapientum, Genotype AAA) and Sabri (M sapientum, Genotype AAA). The cultivars 'Grand Naine' and 'Sabri' were collected from Horticulture Demonstration and Training Centre (HDTC), Kewatkhali, Mymensingh. The cultivar 'Amritasagar' was collected from Horticulture Farm, Bangladesh Agricultural University, Mymensingh. The shoot tip used for the establishment of culture was prepared from the collected suckers through dissection and removal of leaf sheath.

\section{Plant growth regulator (Solute) Solvents}

Auxins: $\alpha$ - Naphthalene acetic acid (NAA)

Cytokinin: 6-Benzyl amino purine (BAP)

\section{$0.1 \mathrm{~N} \mathrm{NaOH}$}

$0.1 \mathrm{~N} \mathrm{NaOH}$

To prepare a stock solution of growth regulator, $10 \mathrm{mg}$ of the growth regulator was taken on a clean watch glass then dissolved in $1 \mathrm{ml}$ measuring cylinder and the volume was made up to $100 \mathrm{ml}$ with distilled water. The solution was then poured into a clean glass container and stored at $4 \pm 1^{\circ} \mathrm{C}$ and used for a maximum period of two months. The investigation was carried out at Biotechnology laboratory, Bangladesh Agricultural University, Mymensingh and at Horticulture Demonstration and Training Centre, Kewatkhali, Mymensingh during the period from April to November, 2004.

\section{Culture Method}

Preparation of explants: The shoot tip was the starting material and was obtained from developing suckers of banana cultivars. Small suckers of banana were collected from the field and was brought to the preparation room. The suckers were washed thoroughly under running tap water. The older leaves, roots and extraneous corm tissues were carefully removed with the help of a sharp stainless steel knife and chopped into small pieces. The pieces containing shoot tip with several sheathing leaf 
bases enclosing the axillary buds and some corm tissues with pseudostem measuring about $2.0-2.5 \mathrm{~cm}$ length were isolated for further operations.

Surface sterilization and inoculation of explants: The prepared shoot tips were taken in a flask and sterilized by $70 \%$ ethanol for 30 seconds and then explants were washed 3 times with double distilled water. Afterwards the explants were sterilized with $10 \%$ Calcium chloro hypochlorite solution for 10 minutes. Then the $\mathrm{Ca}(\mathrm{OCl}) \mathrm{Cl}$ solution was poured out and the explants were washed several times with Sterile double distilled water to remove $\mathrm{Ca}(\mathrm{OCl}) \mathrm{Cl}$ from the explants. The shoot tip explants about $0.4 \mathrm{~cm}$ long with 3-4 leaf primordia were repaired. The individual shoot tip was directly inoculated to each culture vessel and covered with plastic cap. After that the caps were sealed with parafilm. Finally, the culture vessels were transferred to growth room and were allowed to grow in controlled environment.

\section{Analysis of Data}

The data for the characters under study were statistically analyzed following Completely Randomized Design (CRD). The analysis of variance was performed and means were compared by Least Significant Difference (LSD) test for interpretation of results.

\section{Results and Discussion}

After inoculation of shoot tips to the culture media, the shoot tips showed creamy white appearance (Figure 01) at first sight and gradually became brown to light green, green and finally dark green on MS medium supplemented with different concentrations of BAP used. The color changes were observed regularly which is presented in Table 01 . The extent of color changes was recorded at 15 days and 30 DAI. The response of color change of the explants of Grand Naine, Amritasagar and Sabri varied in respect of time and concentrations of BAP used (Table 01). The explant of Grand Naine and Amritasagar became dark green at $2.0 \mathrm{mg} / \mathrm{L}$ to $5.0 \mathrm{mg} / \mathrm{L}$ BAP after 15 DAI but at $1.0 \mathrm{mg} / \mathrm{L}$ and $6.0 \mathrm{mg} / \mathrm{L} \mathrm{BAP}$ the inoculated explants turned green in color. After $30 \mathrm{DAI}$ all the explants turned dark green in color except in control.

Table 01. Relative color change of the explants from three banana cultivars at different concentrations of BAP

\begin{tabular}{|c|c|c|c|c|c|c|}
\hline \multirow{3}{*}{$\begin{array}{l}\text { BAP } \\
(\mathrm{mg} / \mathrm{L})\end{array}$} & \multicolumn{6}{|c|}{ Banana cultivars } \\
\hline & \multicolumn{2}{|l|}{ Grand Naine } & \multicolumn{2}{|l|}{ Amritasagar } & \multicolumn{2}{|l|}{ Sabri } \\
\hline & $\begin{array}{l}\text { Colour } \\
\text { change after } \\
15 \text { days }\end{array}$ & $\begin{array}{l}\text { Colour } \\
\text { change after } \\
30 \text { days }\end{array}$ & $\begin{array}{l}\text { Colour } \\
\text { change after } \\
15 \text { days }\end{array}$ & $\begin{array}{l}\text { Colour } \\
\text { change after } \\
30 \text { days }\end{array}$ & $\begin{array}{l}\text { Colour } \\
\text { change after } \\
15 \text { days }\end{array}$ & $\begin{array}{l}\text { Colour } \\
\text { change after } \\
30 \text { days }\end{array}$ \\
\hline 0.0 & + & ++ & + & ++ & B & + \\
\hline 1.0 & ++ & +++ & ++ & +++ & + & +++ \\
\hline 2.0 & +++ & +++ & +++ & +++ & ++ & +++ \\
\hline 3.0 & +++ & +++ & +++ & +++ & ++ & +++ \\
\hline 4.0 & +++ & +++ & +++ & +++ & ++ & +++ \\
\hline 5.0 & +++ & +++ & +++ & +++ & ++ & +++ \\
\hline 6.0 & ++ & +++ & ++ & +++ & + & +++ \\
\hline
\end{tabular}

Legend: $\mathrm{B}=$ Brown,+ = Light green,++ = Green,+++ = Dark green

In case of Sabri, relative color change was quite different from the other cultivars. The response of color change of Sabri varied in respect of time and concentrations of BAP (Table 01). After 15 days the color change was green for BAP concentrations of $2.0 \mathrm{mg} / \mathrm{L}$ to $5.0 \mathrm{mg} / \mathrm{L}$ but at $1.0 \mathrm{mg} / \mathrm{L}$ and $6.0 \mathrm{mg} / \mathrm{L}$ BAP the explants turned light green in color, and in control the explants became brown in color. On the other hand, after 30 days of inoculation all the explants turned dark green in color for all the concentrations of BAP used except in control. In control, the color was light green in Sabri and green in Grand Naine and Amritasagar after 30 DAI. Therefore, it is clear that BAP is important for early greening of the banana cultivars. The above results show that the color change of inoculated explants varied in the same treatment for different varieties. Roca (1992) reported similar results while 
working with 10 varieties of banana in the Philippines. BA and isopentenyl amino purine (2iP) each at low concentration $(1 \mathrm{mg} / \mathrm{L})$ favoured the earliest greening of cv. Senorita (within 40 days) and Saba with respective optimum concentrations of 1.0 and $2.5 \mathrm{mg} / \mathrm{L}$, respectively whereas both cytokinin gave similar effects in Lakatan.

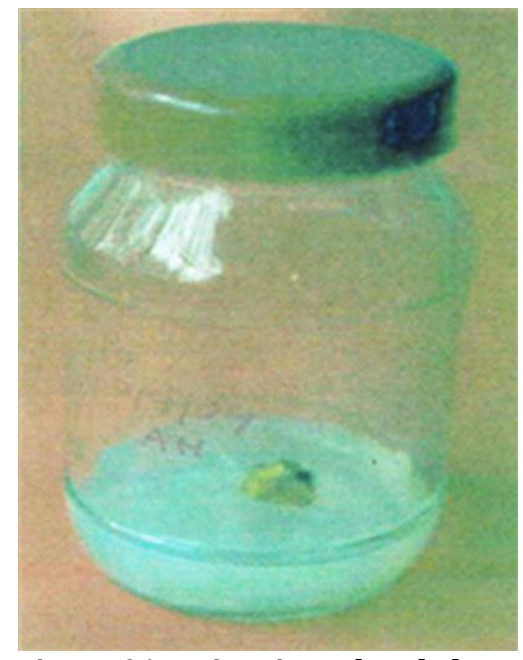

Figure 01. A just inoculated shoot tip isolated from a sucker

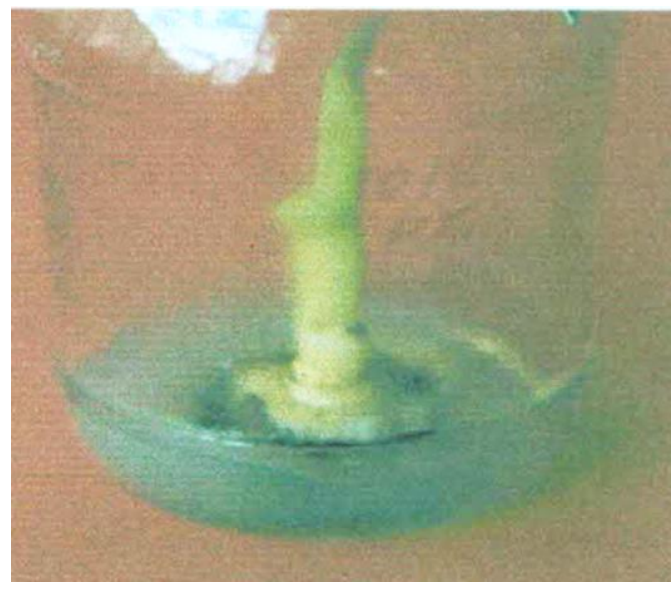

Figure 02. Single shoot of 'Grand Naine' produced on MS medium containing $5.0 \mathrm{mg} / \mathrm{L}$ BAP at 30 days after inoculation (DAI)

Table 02: Effect of BAP on shoot formation of three banana cultivars

\begin{tabular}{|c|c|c|c|c|c|c|c|c|c|}
\hline \multirow[b]{3}{*}{$\begin{array}{l}\text { Concentrations } \\
\text { of BAP (mg/L) }\end{array}$} & \multicolumn{9}{|c|}{ Banana Cultivar } \\
\hline & \multicolumn{3}{|c|}{ Grand Naine } & \multicolumn{3}{|c|}{ Amritasagar } & \multicolumn{3}{|l|}{ Sabri } \\
\hline & 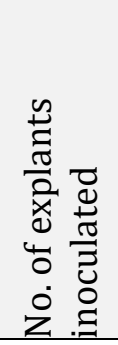 & 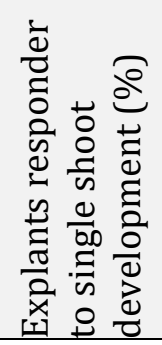 & 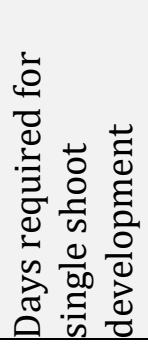 & 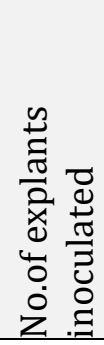 & 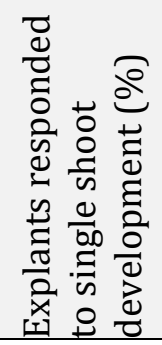 & 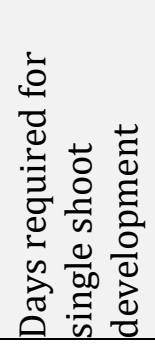 & 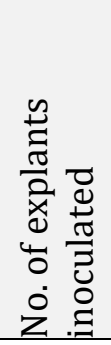 & 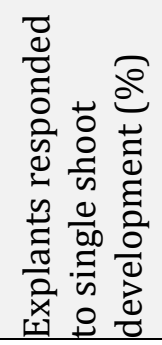 & 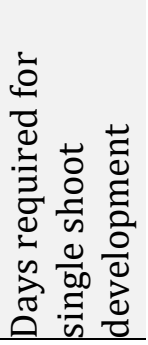 \\
\hline 0.0 & 8 & - & - & - & - & - & - & +1 & - \\
\hline 1.0 & 8 & 15.62 & 11.0 & 8 & 15.62 & 17.5 & 8 & 9.37 & 22.5 \\
\hline 2.0 & 8 & 18.75 & 11.0 & 8 & 18.75 & 12.5 & 8 & 9.37 & 22.5 \\
\hline 3.0 & 8 & 18.75 & 11.0 & 8 & 25.00 & 12.5 & 8 & 12.50 & 21.5 \\
\hline 4.0 & 8 & 25.00 & 11.0 & 8 & 25.00 & 12.5 & 8 & 18.75 & 21.5 \\
\hline 5.0 & 8 & 37.50 & 11.0 & 8 & 40.65 & 12.5 & 8 & 21.87 & 13.5 \\
\hline 6.0 & 8 & 18.75 & 11.0 & 8 & 18.75 & 12.5 & 8 & 15.62 & 22.5 \\
\hline
\end{tabular}

\section{In vitro single shoot induction from shoot tip explants}

For in vitro regeneration, single shoot regeneration is a preliminary event because multiple shooting is impossible without forming single shoot. In tissue culture practice, multiple shoot production is highly desirable. The results on regeneration of single shoot from shoot tip explants have been presented in Table 02. It was observed that the cultivar Grand Naine produced single shoot in all the treatment except control. The highest percentage $(37.50 \%)$ of explants produced single shoot in Grand Naine at $5.0 \mathrm{mg} / \mathrm{L} \mathrm{BAP}$, whereas the lowest percentage $(15.62 \%)$ of explants at $1.0 \mathrm{mg} / \mathrm{L} \mathrm{BAP}$. Days required for single shoot regeneration was the same for different concentration of BAP used (Table 02).

In case of Amritasagar, the highest percentage (40.62\%) of single shoot regeneration was observed at $5.0 \mathrm{mg} / \mathrm{L} \mathrm{BAP}$, whereas the lowest percentage (15.62\%) at $1.0 \mathrm{mg} / \mathrm{L}$ BAP (Table 02). In addition, there was variation in days required for single shoot regeneration at different concentrations of BAP used. It was observed from the result that single shoot regeneration was lower in case of cultivar Sabri compared to Grand Naine and Amritasagar (Figure 02, 03 \& 04). In case of Sabri the highest 
percentage $(21.87 \%)$ of explants produced single shoot at $5.0 \mathrm{mg} / \mathrm{L}$ BAP, whereas the lowest percentage $(9.37 \%)$ at $1.0 \mathrm{mg} / \mathrm{L}$ and $2.0 \mathrm{mg} / \mathrm{L} \mathrm{BAP}$. The time required for single shoot regeneration was higher than in Grand Naine and Amritasagar (Table 02).

The results presented in Table 02 shown that in all the BAP concentrations, single shoot were produced but percentage of single shoot regeneration increased with the increase of BAP concentration up to $5.0 \mathrm{mg} / \mathrm{l}$ and thereafter declined. The cultivars responded to different concentration of BAP was different. Response of Amritasagar was the highest (40.6\%) followed by Grand Naine (37.50\%) and Sabri (21.87\%), respectively. In all the cultivars, shoots did not proliferate when BAP was omitted from the medium. Rehana (1999) found that time requirement for single shoot formation (10-15 days) which was close to the present investigation. The results indicated that single shoot formation from shoot tip explant gradually increased with the increase in BAP concentration up to $5.0 \mathrm{mg} / \mathrm{L}$, and then declined at $6.0 \mathrm{mg} / \mathrm{L}$. The results of the present investigation were also more or less similar to the findings of Rabbani et al. (1996).

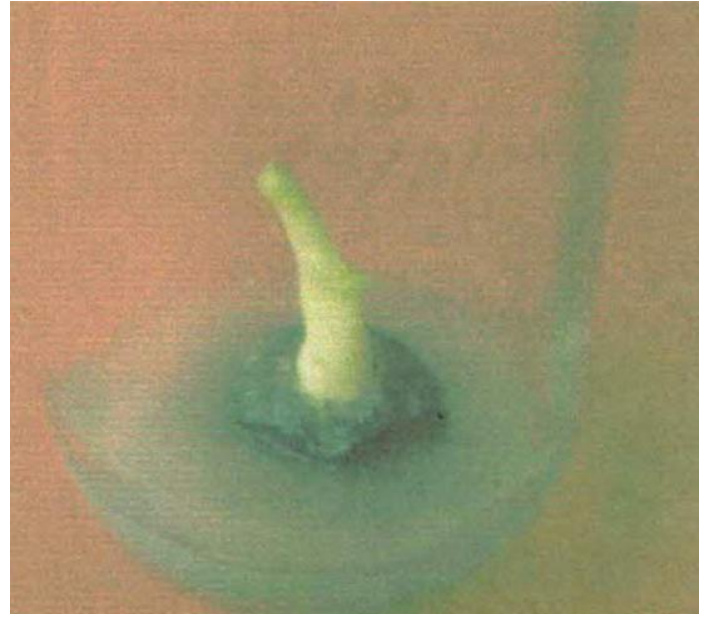

Figure 03. Single shoot of 'Amritasagaor' produced on MS medium containing $5.0 \mathrm{mg} / \mathrm{L}$ BAP at 30 days after inoculation (DAI).

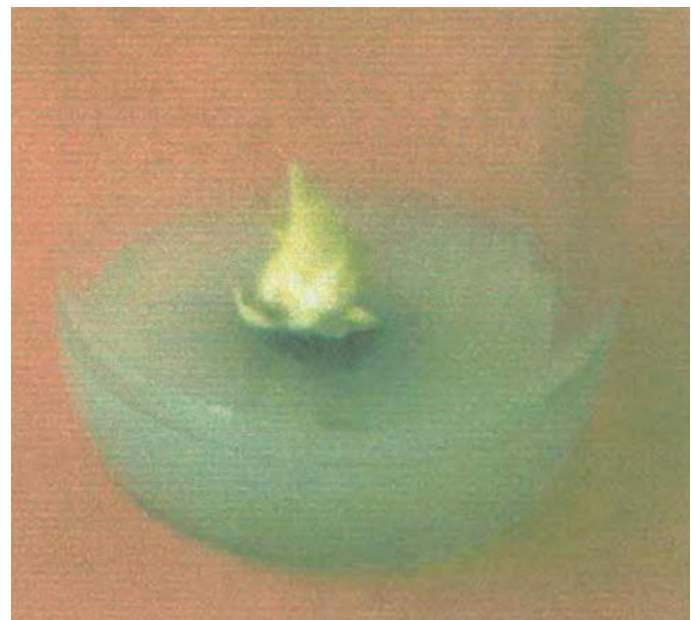

Figure 04. Single shoot of 'Amritasagaor' produced on MS medium containing $5.0 \mathrm{mg} / \mathrm{L}$ BAP at 30 days after inoculation (DAI).

\section{Effect of different concentrations of BAP on shoot proliferation from shoot tip explant}

MS medium supplemented with different concentrations of BAP was used in this experiment. Healthy and vigorous suckers were collected and cut into pieces having half stem and half rhizome. Moreover, a piece of 1.0-1.5 cm long and about $2.0 \mathrm{~cm}$ diameter plantlets were used as primary culture (explant) for shoot proliferation.

Number of shoots per explant: The number of shoots produced per explant varied with different cultivars and concentrations of BAP $(1.0,2.0,3.0,4.0,5.0$ and $6.0 \mathrm{mg} / \mathrm{L})$. Data were recorded at 10, 20 and $30 \mathrm{DAI}$ and results have been presented in Table 03 and 04 . The main effect of BAP on shoot proliferation was significant. The results showed that the cultivar Amritasagar gave the highest (1.64/explant) number of shoots while the lowest (1.07/explant) number of shoots was found in Sabri at 30 DAI. The concentration of BAP $(5.0 \mathrm{mg} / \mathrm{L})$ gave the highest number of shoots at 10, 20 and 30 DAI. The highest number of shoots was proliferated (2.66/explants at $30 \mathrm{DAI})$ with $5.0 \mathrm{mg} / \mathrm{L}$ BAP followed by 2.08/explant and 0.91/explant at 20 DAI and 10 DAI respectively. The lowest (1.25/explant at $30 \mathrm{DAI})$ number of shoots was obtained with $1.0 \mathrm{mg} / \mathrm{L}$ and $2.0 \mathrm{mg} / \mathrm{L}$ BAP. No response took place in hormone free media (Table 03).The combined effect of different cultivars and concentrations of BAP on shoot proliferation has been presented in Table 04. Among the concentrations of BAP supplemented with MS media, $5.0 \mathrm{mg} / \mathrm{l}$ BAP showed the highest shoot proliferation (3.50/explant) of Grand Naine followed by 3.25/explant and 1.75/explant at 30 DAI of Amritasagar and Sabri, respectively (Figure 5, 6 \& 7). The lowest number (1.20/explant at $30 \mathrm{DAI}$ ) of shoot was found in $1.0 \mathrm{mg} / \mathrm{l} \mathrm{BAP.} \mathrm{In} \mathrm{a} \mathrm{study,} \mathrm{Amritsagar} \mathrm{banana} \mathrm{(AAA)} \mathrm{meristem} \mathrm{tip} \mathrm{generated} \mathrm{the}$ highest number of shoots on MS medium supplemented with $30 \mu$ MBAP (Khanam et al. 1996).

Shoot length: The length of shoots produced per explant also influenced by MS media supplemented with different cultivars and concentrations of BAP. Data were recorded at 10, 20 and 30 DAI and 
results have been presented in Table 04 . The combined effect of different cultivars and concentrations of BAP on leaf formation has been presented in Table 04. Among the BAP concentrations in MS media, $5.0 \mathrm{mg} / \mathrm{L}$ BAP showed the highest shoot increment $(4.75 \mathrm{~cm})$ of Grand Naine followed by $5.0 \mathrm{mg} / \mathrm{L}$ BAP treatment where Amritasagar and Sabri showed $3.87 \mathrm{~cm}$ and $2.02 \mathrm{~cm}$ at 30 DAI, respectively. The shortest $(1.40 \mathrm{~cm}$ at $30 \mathrm{DAI})$ shoot was found in $1.0 \mathrm{mg} / \mathrm{L}$ BAP (Table 04). Rabbani et al. (1996) found similar results from $5.0 \mathrm{mg} / \mathrm{L}$ BAP supplemented MS media. During the culture period, it was also noted that there was fluctuation in increment of shoot length with all the media supplemented with different concentrations of BAP used. Therefore, the rate of increase was faster in $5.0 \mathrm{mg} / \mathrm{L} \mathrm{BAP}$ supplemented with MS media (Table 04). The results of the investigation agreed with the findings of Khanam et al. (1996) who obtained the longest shoot in banana on MS medium supplemented with 25 $\mu \mathrm{M} / \mathrm{L} \mathrm{BAP}$.

Number of leaves per plantlet: The number of leaves produced per explant varied on MS media supplemented with different cultivars and concentrations of BAP. Data were recorded at 10, 20 and 30 DAI and results have been presented in Table $03 \& 05$. The main effect of BAP on leaf formation was found significant. The results showed that the cultivar Grand Naine gave the greatest (2.96/plantlet) number of leaves while the lowest (2.46/plantlet) was in Sabri at 30 DAI. BAP at $5.0 \mathrm{mg} / \mathrm{L}$ gave the greatest (4.50/plantlet) number of leaves at $30 \mathrm{DAI}$ followed by 2.33 /plantlet and 0.91 /plantlet at 20 and $10 \mathrm{DAI}$, respectively. The lowest (2.13/plantlet) number of leaves was found with $1.0 \mathrm{mg} / \mathrm{L} \mathrm{BAP}$ at 30 DAI (Table 03).

The combined effect of different cultivars and concentrations of BAP on leaf formation has been presented in Table 05 . BAP at $5.0 \mathrm{mg} / \mathrm{L}$ produced the greatest number of leaves (5.50/plantlet) of Grand Naine followed by 4.50/plantlet and 3.50/plantlet at 30 DAI of Arnritasagar and Sabri, respectively. The shortest (2.25/plantlet at $30 \mathrm{DAI})$ number of leaves was found with $1.0 \mathrm{mg} / \mathrm{L} \mathrm{BAP} \mathrm{of}$ Grand Naine and Sabri. So the present results revealed that Grand Naine is superior to Amritasagar and Sabri in respect to shoot formation (Table 05). The results of the present experiment also agree with the findings of Rabbani et al. (1996) who obtained the similar results from $5.0 \mathrm{mg} / \mathrm{L}$ BAP, which are closed to this finding.

Table 03. Main effect of different cultivars and concentrations of BAP on number of shoots and leaves at different days after inoculation

\begin{tabular}{lllllll}
\hline \multirow{2}{*}{ Treatments } & \multicolumn{3}{c}{ Number of shoots/explants } & \multicolumn{3}{c}{ Number of leaves/plantlet } \\
\cline { 2 - 7 } & 10 Days & 20 Days & 30 Days & 10 days & 20 Days & 30 Days \\
\hline Cultivar & 0.57 & 1.39 & 1.53 & 0.46 & 1.60 & 2.96 \\
\hline Grand Naine & 0.46 & 1.32 & 1.64 & 0.46 & 1.28 & 2.78 \\
Amritasagar & 0.00 & 0.85 & 1.07 & 0.00 & 1.10 & 2.46 \\
Sabri & 0.2048 & 0.2734 & 0.3997 & 0.1962 & 0.3685 & 0.2649 \\
LSD(0.05) & 0.00 & 0.00 & 0.00 & 0.00 & 0.00 & 0.00 \\
\hline BAP Concentration (mg/L) & 0.25 & 0.75 & 1.25 & 0.25 & 1.00 & 2.13 \\
\hline 0 & 0.25 & 1.41 & 1.25 & 0.25 & 1.25 & 2.75 \\
1 & 0.25 & 1.58 & 1.50 & 0.25 & 1.50 & 3.08 \\
2 & 0.41 & 1.58 & 1.83 & 0.41 & 1.91 & 3.75 \\
3 & 0.91 & 2.08 & 2.66 & 0.91 & 2.33 & 4.50 \\
4 & 0.33 & 0.91 & 1.41 & 0.08 & 1.33 & 2.75 \\
5 & 0.3128 & 0.4176 & 0.6105 & 0.2998 & 0.5629 & 0.4046 \\
6 & \multicolumn{7}{c}{} \\
\hline
\end{tabular}

Leaf length: The length of leaves produced per explant varied on MS media supplemented with different cultivars and concentrations of BAP. Data were recorded at 10, 20 and 30 DAI and the combined effect of different cultivars and concentrations of BAP on leaf length have been presented in Table 05 . BAP at $5.0 \mathrm{mg} / \mathrm{L}$ showed the highest leaf length $(2.42 \mathrm{~cm})$ of Grand Naine followed by 2.35 $\mathrm{cm}$ and $2.37 \mathrm{~cm}$ at $30 \mathrm{DAI}$ of Amritasagar and Sabri, respectively. The least length $(1.27 \mathrm{~cm}$ at $30 \mathrm{DAI})$ of leaf was found in Sabri at $1.0 \mathrm{mg} / \mathrm{L}$ BAP (Table 05). These results are in partial support of Rabbani et al. (1996) where they found that highest length of leaf per explant with $5.0 \mathrm{mg} / \mathrm{L}$ each of BAP and 
Kinetin. This variation might be due to the differences of species and inoculated explant. Khanam et al. (1996) and Rehana (1999) also reported the same results.

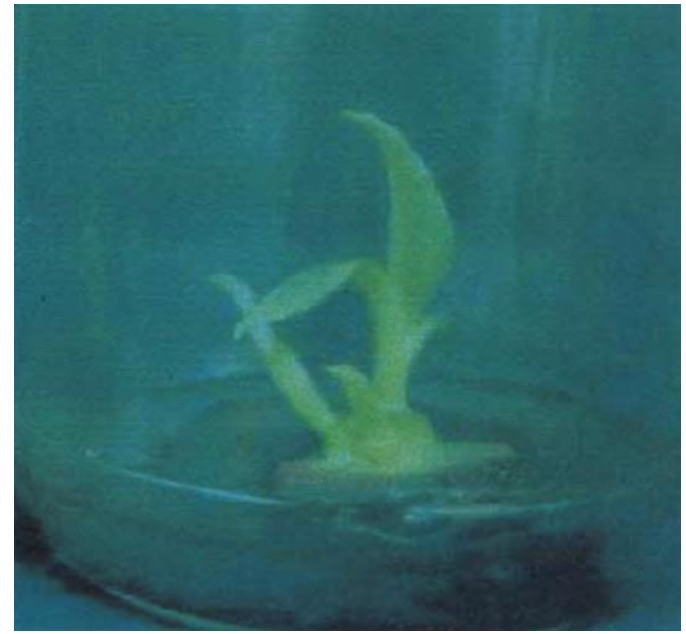

Figure 05. Multiple shoots of 'Amritasagaor' produced on MS medium containing $5.0 \mathrm{mg} / \mathrm{L}$ BAP at 30 days after inoculation.

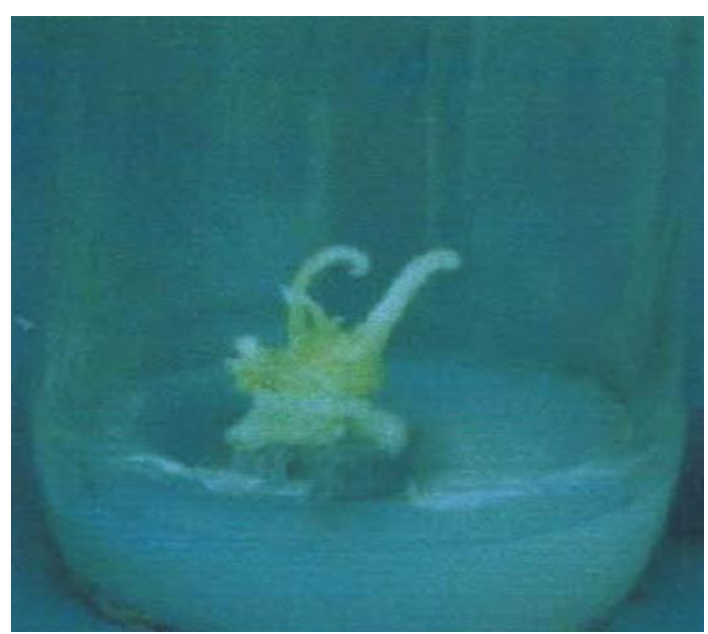

Figure 07. Multiple shoots of 'Amritasagaor' produced on MS medium containing $5.0 \mathrm{mg} / \mathrm{L}$ BAP at 30 days after inoculation.

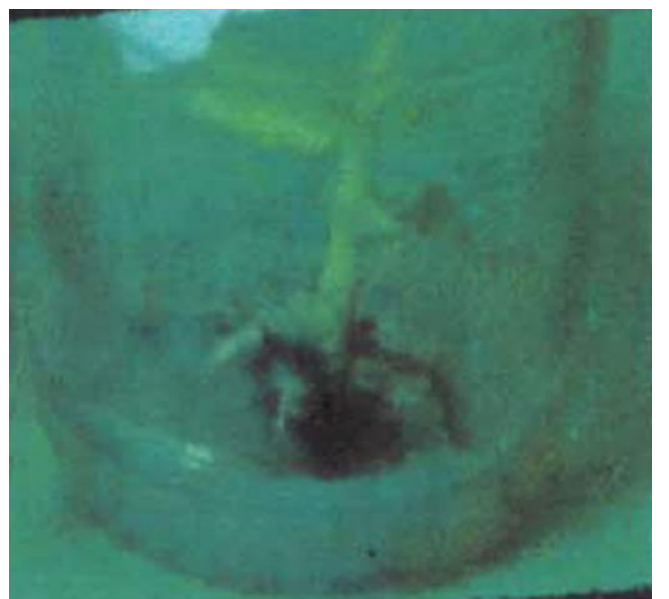

Figure 09. Root formation of 'Amritasagaor' on MS medium containing $4.0 \mathrm{mg} / \mathrm{L}$ NAA at 30 days after inoculation.

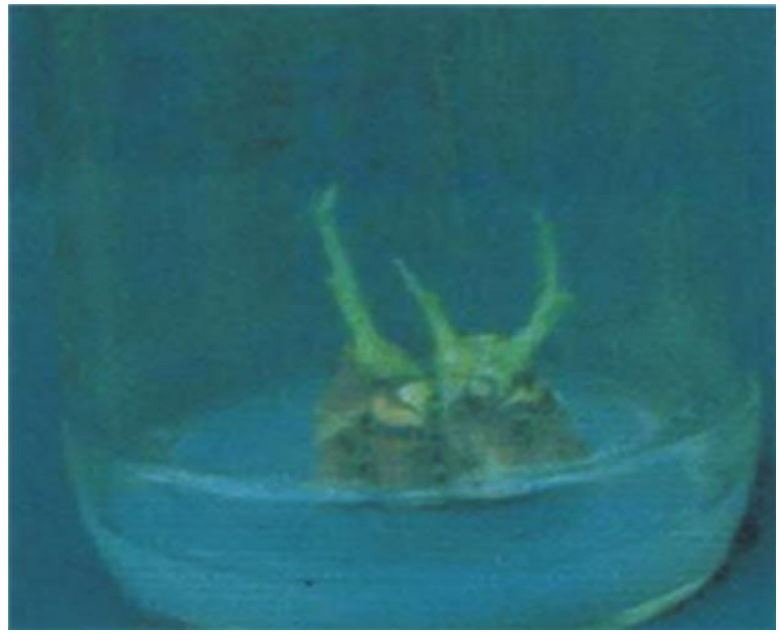

Figure 06. Multiple shoots of 'Amritasagaor' produced on MS medium containing $5.0 \mathrm{mg} / \mathrm{L}$ BAP at 30 days after inoculation.

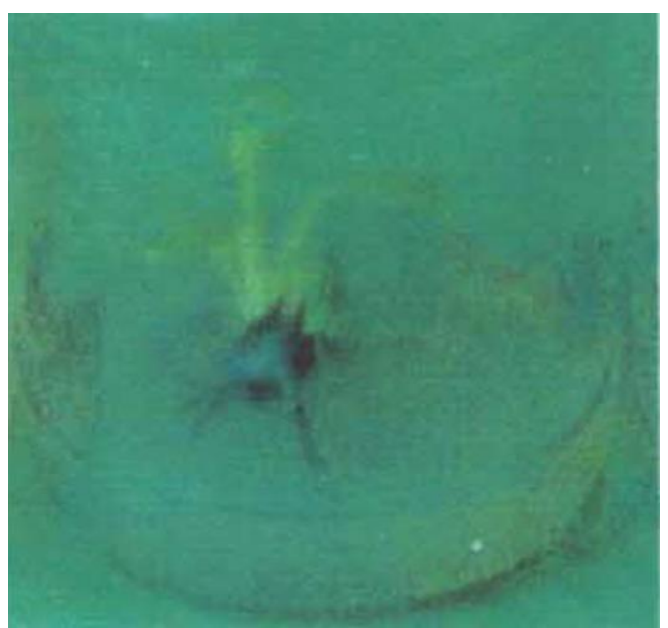

Figure 08. Root formation of 'Grand Naine' on MS medium containing $4.0 \mathrm{mg} / \mathrm{L}$ NAA at 30 days after inoculation (DAI).

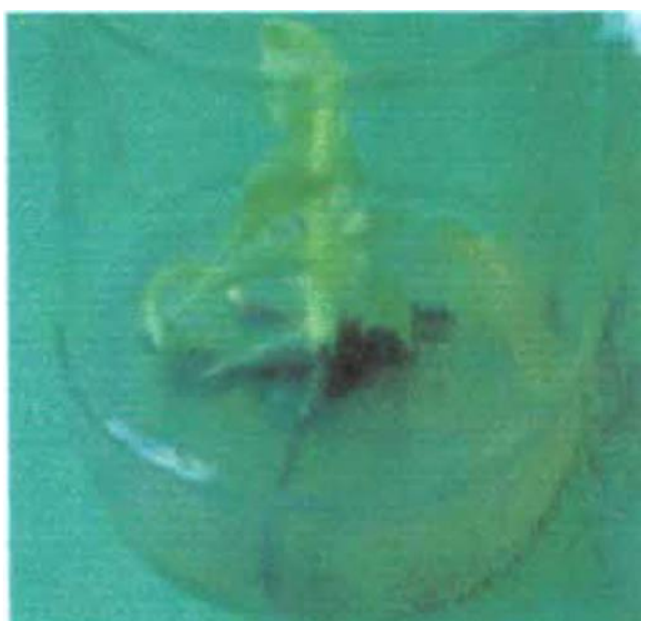

Figure 10. Root formation of 'Sabri' on MS medium containing $4.0 \mathrm{mg} / \mathrm{L}$ NAA at 30 days after inoculation. 
Table 04. Combined effect of cultivars and BAP concentration on number of shoots and length of shoot at different days after inoculation

\begin{tabular}{|c|c|c|c|c|c|c|c|}
\hline \multirow{2}{*}{ Cultivar } & \multirow{2}{*}{$\begin{array}{l}\text { BAP Conc. } \\
(\mathrm{mg} / \mathrm{L})\end{array}$} & \multicolumn{3}{|c|}{ Number of shoots/explants } & \multicolumn{3}{|c|}{ Length of shoot $(\mathrm{cm})$} \\
\hline & & 10 Days & 20 Days & 30 Days & 10 Days & 20 Days & 30 Days \\
\hline \multirow{7}{*}{ Grand Naine } & 0 & 0.00 & 0.00 & 0.00 & 0.00 & 0.00 & 0.00 \\
\hline & 1 & 0.25 & 1.00 & 1.25 & 0.52 & 1.10 & 1.87 \\
\hline & 2 & 0.50 & 1.50 & 1.50 & 0.60 & 1.20 & 1.92 \\
\hline & 3 & 0.75 & 1.50 & 1.75 & 1.50 & 1.92 & 2.62 \\
\hline & 4 & 1.00 & 1.50 & 2.00 & 1.17 & 1.87 & 2.62 \\
\hline & 5 & 1.25 & 2.50 & 3.50 & 2.20 & 4.12 & 4.75 \\
\hline & 6 & 0.75 & 1.50 & 1.50 & 1.02 & 1.65 & 2.42 \\
\hline \multirow{7}{*}{ Amritasagar } & 0 & 0.00 & 0.00 & 0.00 & 0.00 & 0.00 & 0.00 \\
\hline & 1 & 0.50 & 1.25 & 1.25 & 0.32 & 1.37 & 1.85 \\
\hline & 2 & 0.62 & 1.50 & 1.50 & 0.12 & 1.22 & 2.00 \\
\hline & 3 & 0.75 & 1.50 & 2.00 & 0.30 & 1.40 & 2.20 \\
\hline & 4 & 0.96 & 1.75 & 2.00 & 0.17 & 2.12 & 2.87 \\
\hline & 5 & 1.50 & 2.00 & 3.25 & 1.05 & 3.50 & 3.87 \\
\hline & 6 & 0.70 & 1.25 & 1.50 & 0.20 & 1.40 & 2.10 \\
\hline \multirow{7}{*}{ Sabri } & 0 & 0.00 & 0.00 & 0.00 & 0.00 & 0.00 & 0.00 \\
\hline & 1 & 0.00 & 0.00 & 1.25 & 0.00 & 0.00 & 1.39 \\
\hline & 2 & 0.00 & 0.75 & 1.25 & 0.00 & 1.07 & 1.80 \\
\hline & 3 & 0.00 & 1.00 & 1.50 & 0.00 & 1.27 & 1.92 \\
\hline & 4 & 0.00 & 1.50 & 1.50 & 0.00 & 1.40 & 1.95 \\
\hline & 5 & 0.00 & 1.75 & 1.75 & 0.00 & 1.42 & 2.02 \\
\hline & 6 & 0.00 & 0.00 & 1.25 & 0.00 & 0.00 & 1.42 \\
\hline$L S D_{(0.05)}$ & & 0.5418 & 0.7233 & 1.057 & 0.3374 & 0.3344 & 0.3895 \\
\hline
\end{tabular}

\section{Effect of NAA on the regeneration of roots from multiplied shoots of three banana cultivars}

The regenerated shoots were sub cultured on MS medium supplemented with different concentrations of NAA $(0.5,1.0,2.0,4.0$ and $6.0 \mathrm{mg} / \mathrm{L})$ in order to allow root formation. Roots numbers and length of roots varied with different concentrations of NAA. The results on the effect of different concentrations of NAA on root formation have been presented in Table 06 and 07.

Number of roots/explant: The number of roots produced per explant varied on MS media supplemented with different cultivars and concentrations of NAA $(0.5,1.0,2.0,4.0$ and $6.0 \mathrm{mg} / \mathrm{L})$ used. Data were recorded at 10, 20 and 30 DAI (Table $06 \& 07$ ). The main effect of NAA on root formation was found significant. The results showed that the cultivar Grand Naine gave the highest (3.55/plantlet) number of roots and lowest (2.94/plantlet) number of roots found in Sabri at 30 DAI (Table 06). The concentration of $4.0 \mathrm{mg} / \mathrm{L}$ NAA gave the highest number of roots at 10, 20 and 30 DAI. The highest number of roots were observed (5.11/plantlet at $30 \mathrm{DAI})$ with $4.0 \mathrm{mg} / \mathrm{L} \mathrm{NAA}$ followed by $4.77 /$ plantlet and 3.00/plantlet at $20 \mathrm{DAI}$ and $10 \mathrm{DAI}$, respectively. The lowest numbers of roots were obtained with $0.5 \mathrm{mg} / \mathrm{L}$ NAA (Table 06). At different DAI, the combined effect of NAA also showed significant variation in root number. The highest number of roots (5.66/explant) was obtained from $4.0 \mathrm{mg} / \mathrm{L}$ NAA of Grand Naine (Table 07) and the lowest (2.33/explant) number of roots was obtained from $0.5 \mathrm{mg} / \mathrm{l} \mathrm{NAA}$ of Sabri at 3050 DAI whereas no response was observed in control condition. The number of root produced/plantlet increased with the increase of NAA concentration up to $4.0 \mathrm{mg} / \mathrm{L}$ and declined thereafter. Moreover, the root number was increased with the increase of DAl (Table 07). So the present results reveal that Grand Naine is superior to Amritasagar and Sabri in respect to root formation (Figure 08, 09 \& 10). Rahman et al. (2002) found similar results from $4.0 \mathrm{mg} / \mathrm{L} \mathrm{NAA}$ supplemented MS media. During the culture period, it was also noted that there was fluctuation in increment of root length with all the media supplemented with different concentrations of NAA and was also reported by Bhaskar et al. (1993) observed best in vitro rooting on Knudson's medium supplemented with $4.0 \mathrm{mg} / \mathrm{L}$ NAA. 
Table 05. Combined effect of cultivars and BAP concentrations on number of leaf and leaf length at different days after inoculation

\begin{tabular}{|c|c|c|c|c|c|c|c|}
\hline \multirow[b]{2}{*}{ Cultivar } & \multirow{2}{*}{$\begin{array}{l}\text { BAP Conc. } \\
\text { (mg/L) }\end{array}$} & \multicolumn{3}{|c|}{ Number of leaves } & \multicolumn{3}{|c|}{ Leaf length $(\mathrm{cm})$} \\
\hline & & 10 Days & 20 Days & 30 Days & 10 Days & 20 Days & 30 Days \\
\hline \multirow{7}{*}{ Grand Naine } & 0 & 0.00 & 0.00 & 0.00 & 0.00 & 0.00 & 0.00 \\
\hline & 1 & 0.25 & 1.50 & 2.25 & 0.45 & 1.05 & 1.30 \\
\hline & 2 & 0.50 & 1.75 & 2.75 & 0.52 & 1.05 & 1.75 \\
\hline & 3 & 0.25 & 1.50 & 3.25 & 0.30 & 1.17 & 1.50 \\
\hline & 4 & 1.00 & 2.25 & 4.50 & 0.65 & 1.25 & 1.72 \\
\hline & 5 & 1.25 & 2.75 & 5.50 & 0.27 & 1.35 & 2.42 \\
\hline & 6 & 0.00 & 1.50 & 2.50 & 0.00 & 1.07 & 1.25 \\
\hline \multirow{7}{*}{ Amritasagar } & 0 & 0.00 & 0.00 & 0.00 & 0.00 & 0.00 & 0.00 \\
\hline & 1 & 0.50 & 1.50 & 2.50 & 0.37 & 1.10 & 1.37 \\
\hline & 2 & 0.25 & 1.00 & 2.75 & 0.25 & 1.10 & 1.65 \\
\hline & 3 & 0.50 & 1.50 & 3.25 & 0.48 & 1.20 & 1.77 \\
\hline & 4 & 0.25 & 1.75 & 3.25 & 0.27 & 1.35 & 1.87 \\
\hline & 5 & 1.50 & 2.00 & 4.50 & 1.05 & 1.47 & 2.35 \\
\hline & 6 & 0.25 & 1.25 & 3.25 & 0.25 & 1.10 & 1.92 \\
\hline \multirow{7}{*}{ Sabri } & 0 & 0.00 & 0.00 & 0.00 & 0.00 & 0.00 & 0.00 \\
\hline & 1 & 0.00 & 1.00 & 2.25 & 0.00 & 0.75 & 1.27 \\
\hline & 2 & 0.00 & 1.00 & 2.75 & 0.00 & 1.00 & 1.52 \\
\hline & 3 & 0.00 & 1.50 & 2.75 & 0.00 & 1.07 & 1.65 \\
\hline & 4 & 0.00 & 1.75 & 3.50 & 0.00 & 1.07 & 2.22 \\
\hline & 5 & 0.00 & 2.25 & 3.50 & 0.00 & 1.00 & 2.37 \\
\hline & 6 & 0.00 & 1.25 & 2.50 & 0.00 & 0.77 & 1.46 \\
\hline$L S D_{(0.05)}$ & & 0.5192 & 0.9749 & 0.7008 & 0.5173 & 0.2567 & 0.3518 \\
\hline
\end{tabular}

Table 06. Varietal effect (main) of different cultivars and concentrations of NAA on root number and root length at different days after inoculation.

\begin{tabular}{lllllll}
\hline \multirow{2}{*}{ Treatments } & \multicolumn{3}{l}{ Root numbers/plantlet } & \multicolumn{3}{l}{ Root length $(\mathrm{cm})$} \\
\cline { 2 - 7 } & 10 Days & 20 Days & 30 Days & 10 days & 20 Days & 30 Days \\
\hline Cultivar & & & & & & \\
\hline Grand Naine & 1.72 & 2.66 & 3.55 & 0.86 & 1.26 & 1.63 \\
Amritasagar & 1.50 & 2.66 & 3.44 & 0.80 & 1.09 & 1.68 \\
Sabri & 1.55 & 2.38 & 2.94 & 0.76 & 1.04 & 1.61 \\
LSD(0.05) & 0.3678 & 0.3564 & 3.2564 & 0.1924 & 0.3091 & 0.1481 \\
\hline NNA Concentration (mg/L) & & & & & \\
\hline 0 & 0.00 & 0.00 & 0.00 & 0.00 & 0.00 & 0.00 \\
0.5 & 1.44 & 2.44 & 3.33 & 0.87 & 1.27 & 1.63 \\
1 & 1.11 & 2.33 & 3.44 & 0.55 & 0.80 & 2.03 \\
2 & 2.33 & 3.33 & 4.33 & 1.22 & 1.65 & 2.02 \\
4 & 3.00 & 4.77 & 5.11 & 1.35 & 1.85 & 2.37 \\
6 & 1.66 & 2.55 & 3.66 & 0.88 & 1.22 & 1.80 \\
$L S D(0.05)$ & 0.5201 & 0.5041 & 0.5041 & 0.2721 & 0.4371 & 0.2095 \\
\hline
\end{tabular}

Root length: A significant variation in the root length developed by the plantlets was influenced considerably by MS media supplemented with different cultivars and concentrations of NAA $(0.5,1.0$, 2.0, 4.0 and $6.0 \mathrm{mg} / \mathrm{L}$ ). Data were recorded at 10, 20 and $30 \mathrm{DAI}$ and results have been presented in Table 06 and 07 . The main effect of NAA on root increment was found significant. The results showed that the cultivar Amritasagar gave the highest $(1.68 \mathrm{~cm})$ root length and lowest $(1.61 \mathrm{~cm})$ root length found in Sabri at 30 DAl. On the other hand, NAA at $4.0 \mathrm{mg} / \mathrm{L}$ gave the highest root length at 10, 20 and $30 \mathrm{DAl}$. The highest root length was found $(2.37 \mathrm{~cm}$ at $30 \mathrm{DAI})$ with $4.0 \mathrm{mg} / \mathrm{L}$ NAA followed by $1.85 \mathrm{~cm}$ and $1.35 \mathrm{~cm}$ at $20 \mathrm{DAl}$ and $10 \mathrm{DAl}$ respectively. The lowest $(1.63 \mathrm{~cm}$ at $30 \mathrm{DAI})$ root length was obtained with $0.5 \mathrm{mg} / \mathrm{L}$ NAA. No response took place in hormone free media (Table 06). The combined 
effect of different cultivars and concentrations of NAA on root increment have been presented in Table 07. Among the concentrations, NAA at $4.0 \mathrm{mg} / \mathrm{L}$ showed the highest root length $(2.60 \mathrm{~cm})$ of Grand Naine followed by $2.35 \mathrm{~cm}$ and $2.16 \mathrm{~cm}$ at 30 DAI of Amritasagar and Sabri respectively (Table 07). The lowest $(1.53 \mathrm{~cm}$ at $30 \mathrm{DAI})$ root length was found in Amritasagar at $0.5 \mathrm{mg} / \mathrm{L} \mathrm{NAA}$. The result indicated that there was a sharp increase in root length at 10, 20 and 30 DAI. Moreover, root length increased with the increase of NAA concentration up to $4.0 \mathrm{mg} / \mathrm{L}$ and thereafter declined (Table 07). So, the present results revealed that the increment of root length of Grand Naine is superior to other banana cultivars. The present results agree with the findings of Rahman et al. (2002) and Bhaskar et al. (1993).

Table 07. Combined effect of cultivars and NAA concentrations on root number and root length at different days after inoculation.

\begin{tabular}{|c|c|c|c|c|c|c|c|}
\hline \multirow{2}{*}{ Cultivar } & \multirow{2}{*}{$\begin{array}{l}\text { NAA } \\
\text { Conc. }(\mathrm{mg} / \mathrm{L})\end{array}$} & \multicolumn{3}{|c|}{ Root numbers/plantlets } & \multicolumn{3}{|c|}{ Root length (cm) } \\
\hline & & 10 Days & 20 Days & 30 Days & 10 Days & 20 Days & 30 Days \\
\hline \multirow{6}{*}{ Grand Naine } & 0 & 0.00 & 0.00 & 0.00 & 0.00 & 0.00 & 0.00 \\
\hline & 0.5 & 1.33 & 2.33 & 3.33 & 0.83 & 1.40 & 1.66 \\
\hline & 1 & 1.66 & 2.33 & 3.66 & 0.80 & 1.23 & 1.80 \\
\hline & 2 & 2.33 & 3.33 & 4.33 & 1.21 & 1.60 & 2.00 \\
\hline & 4 & 3.33 & 5.33 & 5.66 & 1.53 & 2.06 & 2.60 \\
\hline & 6 & 1.66 & 2.66 & 4.33 & 0.83 & 1.30 & 1.73 \\
\hline \multirow{6}{*}{ Amritasagar } & 0 & 0.00 & 0.00 & 0.00 & 0.00 & 0.00 & 0.00 \\
\hline & 0.5 & 1.66 & 2.66 & 4.33 & 1.00 & 1.26 & 1.53 \\
\hline & 1 & 0.66 & 2.33 & 3.33 & 0.45 & 0.63 & 2.23 \\
\hline & 2 & 2.33 & 3.33 & 4.33 & 1.18 & 1.63 & 1.93 \\
\hline & 4 & 3.33 & 5.33 & 5.33 & 1.38 & 1.93 & 2.35 \\
\hline & 6 & 1.00 & 2.33 & 3.33 & 0.83 & 1.10 & 2.06 \\
\hline \multirow{6}{*}{ Sabri } & 0 & 0.00 & 0.00 & 0.00 & 0.00 & 0.00 & 0.00 \\
\hline & 0.5 & 1.33 & 2.33 & 2.33 & 0.80 & 1.16 & 1.70 \\
\hline & 1 & 1.00 & 2.33 & 3.33 & 0.40 & 0.53 & 2.06 \\
\hline & 2 & 2.33 & 3.33 & 4.33 & 1.26 & 1.73 & 2.13 \\
\hline & 4 & 2.33 & 3.66 & 4.33 & 1.33 & 1.56 & 2.16 \\
\hline & 6 & 2.33 & 2.66 & 3.33 & 1.00 & 1.26 & 1.60 \\
\hline$L S D_{(0.05)}$ & & 0.9009 & 0.8731 & 0.8731 & 0.4713 & 0.7570 & 0.3628 \\
\hline
\end{tabular}

\section{Ex vitro hardening of plantlets}

The plantlets with well-developed roots were removed from the culture vessels without damaging the roots. The agar was washed away from the roots with running tap water. After that, the plantlets were transferred to small polythene bag filled with soil, sand and well decomposed cowdung (1:1:1) and the plantlets along with pot were covered with moist and transparent polythene bag to prevent desiccation. Then the polythene bag containing plantlets were transferred to net house, where proper care was taken for growth and development of banana plantlets. After 10-15 days, maximum plants showed vigorous growth and some of them found relatively weak. Therefore, the plantlets became well hardened and ready to replace in the field conditions after 2 months (Figure 11). The survival rate of plantlets was $100 \%$ in sand, soil and cowdung (1:1:1) containing pot mixture. The present result is consistent with the findings of Cronauer and Krikorian (1984) who reported the successful establishment of in vitro rooted shoots of four banana cultivars on pot mixture containing soil and vermiculate at 1: 1 ratio. It also agrees with the findings of Azad and Amin (1999). 


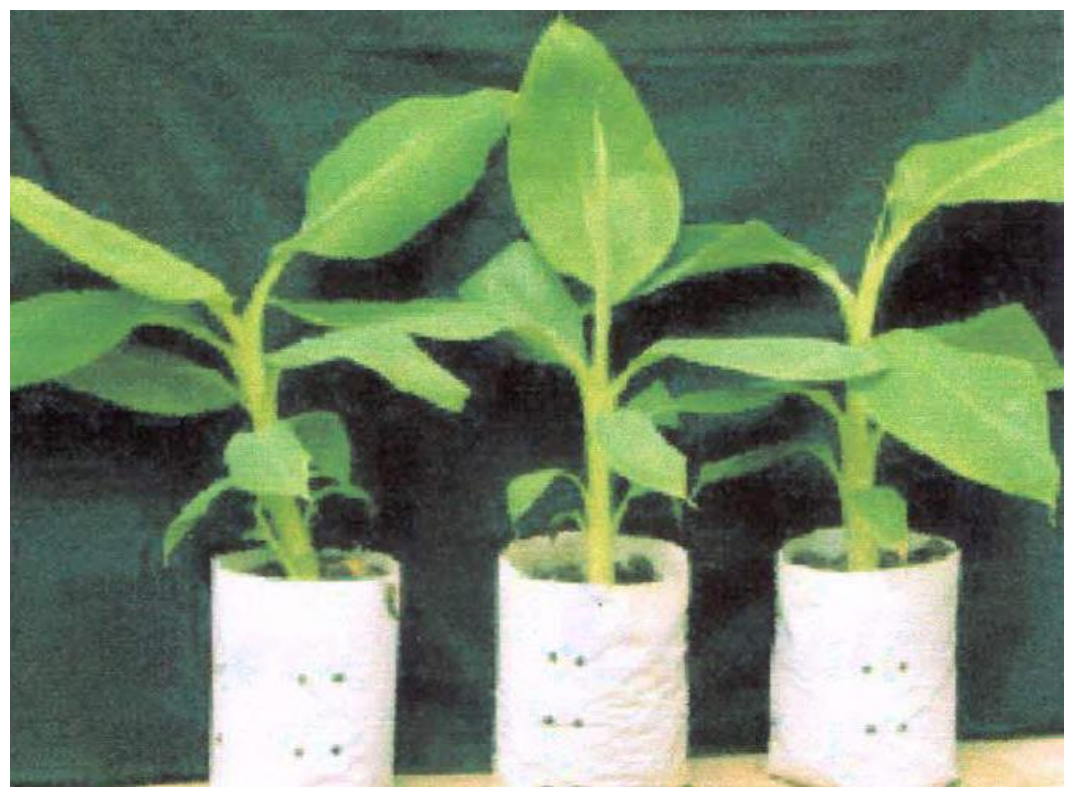

\section{Figure 11. Hardened in vitro grown plantlets of banana cv. after 30 days of transfer to polythene bag.}

\section{Conclusion}

Banana is the staple food for many countries in the world. In the tropical and subtropical region demand for planting material of banana is high. Safe and reliable plant material for propagation is a challenge for farmers. In this respect plant tissue culture can be utilized effectively to solve the problem. In our current study, three banana cultivars (Grand Naine, Amritasagar and Sabri) are used, among them Grand Naine and Amritasagar showed the highest performance. The result of the investigation indicated that banana cultivars Grand Naine and Amritasagar can be successfully multiplied in vitro using $5.0 \mathrm{mg} / \mathrm{L}$ BAP and successive rooting can be achieved using $4.0 \mathrm{mg} / \mathrm{L}$ NAA. The response of the cultivar Sabri was relatively poor. So, further study in this respect is needed to improve the technique of micropropagation for this cultivar.

\section{Reference}

[1]. Azad, M. A. K \& Amin, M. N. (1999). In vitro propagation and conservation of banana (Musa spp.). Abstracts, Third International Plant Tissue Culture Conference held during 8-10 March, 1999, Dhaka, Bangladesh. p. 12.

[2]. Barker, W. G. \& Steward, F. (1962). Growth and Development of the Banana Plant II. The Transition from the Vegetative to the Floral Shoot in Musa acuminata cv. Gros Michel. Annals of Botany, 26(3), 413-423

[3]. BBS. (2003). Statistical Year Book of Bangladesh. Statistics Division. Ministry of Planning, Govt. of the People's Republic of Bangladesh. p. 1351.

[4]. Bhaskar, J., Arvindakchan, M., Valsalakumari, P. K. \& Rajeevan, P. K. (1993). Micro propagation studies in banana. South Indian Horticulture, 41(4), 186-191.

[5]. Cronauer, S. S. \& Krikorian, A. D. (1983). Somatic embryos from culture tissue of triploid plantain (Musa, ABB). Plant Cell Reports, 2(6), 289-291. http://dx.doi.org/10.1007/BF00270183

[6]. Cronauer, S. S. \& Krikorian, A. D. (1984). Multiplication of Musa from excised stem tips. Annals of Botany, 53(3): 321-328. http://aob.oxfordjournals.org/content/53/3/321.abstract

[7]. Faisal, S. M., Hoque, M. A. \& Quasem, A. (1998). Field performance of in vitro plantlets against normal suckers of banana (Musa sapientum) cv. Champa. Plant Tissue Culture, 8(2), 125-129.

[8]. FAO. (1987). Production Year Book 2000. Food and Agriculture Organization of the United Nations. Rome, Italy. Vol. 53, p. 184.

[9]. FAO. (2002). Production Year Book 2000. Food and Agriculture Organization of the United Nations. Rome, Italy. Vol. 65, p. 108. 
[10]. INIBAP. (1987). International Network for the improvement of Banana and Plantaium, publication (October, 1987). Montpellier Cedex (France): pp. 8-9.

[11]. Khanam, D., Hoque, M.A., Khan M. A., \& Quasem, A. (1996). In vitro propagation of banana (Musa spp.). Plant Tissue Culture, 6(2), 89-94.

[12]. Pradeep, K. P., Zachariah, G. Estelittanad, S., \& Suma, A. (1992). Field performance of banana tissue culture plants of variety Nendran (Musa ABB). South Asian Horticulture, 40(1), 1-4.

[13]. Rabbani, M. G., Ali, M. H. \& Mondal, M. F. (1996). Effect of BAP and IBA on micro propagation of some banana cultivars. Bangladesh Horticulture, 25(1\&2), 47-52.

[14]. Rahman, M. M., Rabbani, M. G., Rahman, M .A. \& Uddin, M. F. (2002). In vitro Shoot Multiplication and Rooting of Banana cv. Sabri. Pakistan Journal of Biological Sciences, 5(2), 161-164. http://dx.doi.org/10.3923/pjbs.2002.161.164

[15]. Rehana, S. (1999). Effect of BAP and IBA on in vitro regeneration, shoot multiplication and rooting of four cultivars of banana. MS thesis, Department of Genetics and Plant Breeding, BAU, Mymesnignh. p. 52.

[16]. Roca, H. R. (1992). Floral apex culture of Philippine banana cultivars. College, Laguna (Philippines) Apr. 1992. p. 114.

[17]. Sasson, A. (1997). Importance of tropical and subtropical horticulture, future prospects of biotechnology in tropical and subtropical horticulture species. International Society for Horticulture Science (ISHS), Leuven (Belgium). Acta Horticulturae, 460, 12-26.

[18]. Sharrock, S., \& Frison, E. (1999). Musa production around the world-trends, varieties and regional importance. In: Networking Banana and Plantain. INIBAP Annual Report, 1998, pp. 4247.

\section{CITATIONS}

\section{Citation for this article (APA Style):}

Hossain, M. A., Rubel, M. H., Nasiruddin, K. M. \& Evamoni, F. Z. (2016). Influence of BAP and NAA on in vitro plantlet regeneration of local and exotic banana cultivars. Journal of Bioscience and Agriculture Research, 06(02), 553-564.

\section{MLA (Modern Language Association)}

Hossain, M. A., Rubel, M. H., Nasiruddin, K. M. \& Evamoni, F. Z. "Influence of BAP and NAA on in vitro plantlet regeneration of local and exotic banana cultivars." Journal of Bioscience and Agriculture Research, 06. 02 (2016): 553-564.

\section{Chicago/Turabian}

Hossain, M. A., Rubel, M. H., Nasiruddin, K. M. \& Evamoni, F. Z. "Influence of BAP and NAA on in vitro plantlet regeneration of local and exotic banana cultivars." Journal of Bioscience and Agriculture Research, 06, no. 02 (2016): 553-564.

Submit article and publish with Journal BiNET.

Key Features:

$\checkmark \quad$ Faster processing and review of article

$\checkmark$ Quick review and editorial tasks

$\checkmark \quad$ International editorial and review board

$\checkmark \quad 21$ business day's rapid publication

$\checkmark \quad$ View and read articles powered by Scribd

$\checkmark \quad$ Greater audience readership is ensured for all article

$\checkmark \quad$ Indexing and bibliographic integration of article

$\checkmark$ Social sharing enabled article

Submit article (or email to submit@ journalbinet.com): http://www.journalbinet.com/article-submission-form.html 